\title{
THE SACRAMENTS OF HOPE: A HYPOTHESIS IN SACRAMENTAL THEOLOGY FACING CHALLENGES OF THE 21ST CENTURY
}

\author{
BENEDIKT TOMÁŠ MOHELNÍK OP
}

\begin{abstract}
First of all, the author distinguishes between four types of sacramentality - the universal sacramentality (appropriate to Christ), the extensive sacramentality (appropriate to the Church), the organic sacramentality (appropriate to the seven sacraments) and the concentrated sacramentality (appropriate to the Eucharist). Then, he recapitulates the doctrine as being part of the Church tradition and discerns three types of sacraments - sacraments of the natural order, sacraments of Moses' Law and sacraments of the New Testament. The following part is dedicated to the concept of salvation history describing its various phases as coexisting layers, so people living in one historical era can belong to various stages of the salvation economy related to the particular types of sacraments. The last part includes a hypothesis that sacramental action of the Church should not be reduced to a celebration of the seven New Testament sacraments but she is called upon to operate with the sacraments prior to the New Testament (or pre-New Testament sacraments) as well. The fullness of revelation enables the Church to recognise their authentic aspects. The author finds support for his hypothesis in the teachings of the Second Vatican Council and proposes to call these sacraments prior to the New Testament, the sacraments of hope or the sacraments of humanity.
\end{abstract}

Key words:

Sacramentality; History of salvation; Sacraments prior to the New Testament; Sacraments of humanity; Sacraments of hope

DOI: $10.14712 / 23363398.2020 .41$ 
$\mathrm{T}$ he praxis of ecumenical mourning rituals and their theological reflection, which I encountered through theologians from German Erfurt, ${ }^{1}$ has become an impulse for my own theological enquiry. The basic question I asked myself was: How should these services, as well as other analogical rites, be understood from a perspective of the sanctifying ministry of the Church celebrating the sacraments and, more generally, how should they be approached considering the cultic mission of the Church?

The first exhaustive list of the seven sacraments of the Church can be found in the document of the Second Council of Lyon from 1274. Subsequent magisterial texts are completely constant in this respect. The conciliar text of the High Middle Ages draws on a long previous theological reflection, which gradually deepened and clarified the broad concept of sacramentality, which the conciliar statement did not reduce to the seven sacraments. The multi-layered concept of sacramentality remains the very context of the seven sacraments. It would be an unnecessary and unacceptable reduction to limit the notion of sacramentality to only the seven sacraments since this notion remains theologically open for further reflection. This is not different even in the present, which can be viewed as a challenge to reflect on the theme of sacraments also at the beginning of the 21 st century. ${ }^{2}$ Theological reflection has been too often confined to the area marked out by the seven sacraments, and this is even more true of the pastoral praxis and the approach to the term sacrament spread among the majority of believers. The rich meaning of the term sacrament (sacramentum) or the more general term sacramentality is hardly ever reflected when only considering the seven sacraments celebrated in the Church.

First of all, I would like to define the term sacramentality and distinguish its different types. Then, I will identify several groups of sacraments in the context of salvation history. Finally, based on this ground

$1 \quad$ Within the long-term cooperation between Catholic Theological Faculty of Charles University and Theologisches Forschungskolleg an der Universität Erfurt have been realized a few conferences where the above-mentioned theme has frequently occurred. The last conference was organized on 21-24 March 2019 under the title: 'Sakramente im Kontext. Die theologischen Disziplinen vor neuen Fragestellungen im 21. Jahrhundert'. This text is based on a contribution I presented during this event.

2 Cf. The doctrinal resolution in the letter of the emperor Michael to the pope Gregory X presented at The Second Council of Lyon in 1274 (DH 860). This doctrine is the basis of the catholic approach to sacraments (cf. LG 11; CCC 1113 and 1210). 
plan, I will be able to raise the question of various forms through which the Church is called upon nowadays to realize her sanctifying mission.

\section{The Four Types of Sacramentality}

By differentiation among the types of sacramentality according to my own typology, I refer to various modes of God's action in salvation history. Divine performance is always sacramental in the sense that God communicates spiritual, supernatural, and invisible realities to man through visible things and natural parts of creation. ${ }^{3}$ Each of these modes covers certain groups of sacraments which I shall describe later. Sacramentality approached as a general term, sets up the frame for particular sacraments formed by specific principles.

In the first place, there is a universal sacramentality of the Incarnated Word, the person of Jesus Christ in the mysteries of his human life. This kind of sacramentality is universal because Jesus Christ as a man is the sole and universal mediator between God and humans (1 Tim 2:5). ${ }^{4}$ He is the only one because he embraces all people of all times and there is simply no place for another. He offers to all the gift of divine life, which is universal as well.

The second type is an extensive sacramentality, which is an essential characteristic of the Church. The Second Vatican Council defines the Church as the sacrament itself, ${ }^{5}$ which can be stated in an ontological manner. The sacramentality of the Church involves the sense that she is meant to be spreading through space and time as is evident from the mission Christ has entrusted to her. The sacramentality pertains to the Church in its historical and spatial visibility. This sacramentality includes the entire sanctifying ministry of the Church, primarily executed through the celebration of the seven sacraments of the New

\footnotetext{
See for example Thomas Aquinas, STh III. 61. 1.

4 In the documents of the Second Vatican Council is the unique mediation of Jesus Christ, especially emphasised in the constitution Lumen gentium $\$ 8,28,36,41,49$, 60 and 62 .

5 The term sacrament was used to describe the Church in the second scheme of the conciliar constitution in September 1963. The exact formulation was thoroughly discussed during the preparation of the final fourth version of the document. For a synopsis of the schemes and their presentations during the council see Francisco Gil Hellín, Concilii Vaticani II synopsis: Constitutio dogmatica de Ecclesia Lumen Gentium (Vatican: Libreria editrice Vaticana, 1995), 2-5.
} 
Testament, but also through all the other types of sacraments. There are various forms of Christ's redemptive presence through visible signs in his Church as is described in the documents of the Second Vatican Council, for example in the constitution pertaining to sacred liturgy (SC 7). The extensive sacramentality is actually realised within all ministry of the Church throughout history.

The third type is an organic sacramentality, which implies the concept of the seven concrete sacraments of the Church. The word organic serves to reveal the fact that these sacraments are not individual elements which can be arbitrarily picked and mixed but are organised into an organic whole. Another, perhaps even more important aspect indicated by this term is that Christ's mystical body is structured by all of the seven sacraments. These two aspects are deeply related.

Finally, we are able to characterise so-called concentrated sacramentality, which is associated with the one specific sacrament - the Eucharist. The Eucharist represents a concentration of the Christological aspect of sacramentality as the sacrament of the redemptive presence of Christ's paschal mystery in his personal (he is substantially present as a person) as well as historical (the paschal event is present) dimension. It also contains a concentration of the ecclesial aspect of sacramentality executing the unity of love between the Christ-Head and the Church-body, manifesting the unity among members of the Church in via and being the wedding feast of the sacrificed Lamb and eternal Jerusalem (cf. Rev.). There is probably no aspect of sacramentality which is not involved in the Eucharist. We can surely say that we fully understand the universal, the extensive, and the organic sacramentality thanks to the Eucharist and vice versa; that the treasure of the Eucharist is revealed through the universal, the extensive, and the organic sacramentality.

These four types of sacramentality do not stand separately side by side, and they cannot be understood individually because they arise from each other. Their mutual bond can be depicted as a pyramid with the universal sacramentality at the bottom and the concentrated sacramentality at the top. 


\section{The Three Types of Sacraments}

A sacrament or a mystery refers to the situation when 'we can see one thing and we contemplate another,' as was mentioned by St John Chrysostom $^{6}$ and many others thereafter. A sacrament approached in this way is a concrete symbolic act bearing further spiritual content and is able to cover a much wider spectrum than just the seven sacraments of the New Testament. St. Thomas Aquinas based his definition on the term $\operatorname{sign}^{7}$ and is thereby able to incorporate the sacraments of all phases of the salvation history.

The particular types of sacrament correlate with the phases of salvation history as described in the Old and New Testaments. Church fathers as well as scholastic theologians did not approach the (collective) term sacrament, rendering it into the seven sacraments, but their theological reflection was dealing with its multiple layers. I consider this multi-layered concept of a sacrament to be, for the most part, unacknowledged in current sacramental theology. ${ }^{8}$ Theological tradition distinguishes three types of sacraments following the development of salvation history after the fall. ${ }^{9}$ The corruption of the original harmony in the order of creation and the relationship between man and God is the reason why a human person is able to approach supernatural spiritual realities solely through physical signs; therefore, sacraments appear all along with the redemptive work of God. The first category thus comprises sacraments of the order of creation or the natural order - the sacrifice of Abel (which can be considered as the first sacrament), all acts of divine worship realised by the patriarchs (where the specific place belongs to the sacrifice of Melchizedek), as well as all cultic expressions of faith accomplished by the fathers of Israel before

${ }^{6}$ Hom. on 1 Cor 1:7. St Augustine: 'A sign is a thing which causes us to think of something beyond the impression the thing itself makes upon the senses.' Aurelius Augustinus, De doctrina christiana. II, I, 1. Czech translation and commentary: Aurelius Augustinus, Křestanská vzdèlanost, trans. Nechutová Jana (Praha: Vyšehrad, 2004), 77.

7 See Tomáš Akvinský, O svátostech obecněv Teologické sumé: STh III, q. 60-65, translation, introduction and notes Benedikt Mohelník (Praha: Krystal OP, 2019), 26-35.

8 See Louis-Marie Chauvet, 'La théologie sacramentaire aujourd'hui : quelques axes de recherche à promouvoir,' Recherches de Science Religieuse 97, n. 4 (2009): 492; the author mentions here in positive manner a wide approach to the term sacramentality in patristic and medieval theology but does not develop it further.

9 See Thomas Aquinas, STh III. 61. 3. For Thomas' understanding of sacraments in the context of salvation history see my analysis: Tomáš Akvinský, O svátostech obecně $v$ Teologické sumé, 20-26. 
the calling of Moses in Egypt. St. Thomas Aquinas approaches matrimony as a sacrament of this period, ${ }^{10}$ which gains a new dimension in the order of the New Testament.

The sacraments of the Moses' Law are the next step toward the fulfilment of God's promise of salvation. It encompasses essentially all religious instruction contained in the Pentateuch and evolving within the spiritual and cultic tradition of Israel in history, while new feasts commemorating divine intervention in the passing of time were established. These are all directed towards the one perfect sacrament - the person of the incarnated Word and his mystical body, the Church. The mystery of unity between Christ and the Church is the source of the sacraments of the New Testament gradually recognised as the 'canonical' seven.

\section{A Note to the History of Salvation}

Salvation history is not composed of the individual phases linearly following each other one by one. One period does not begin only with the end of the previous, and the beginning of a new phase does not mean a definite end of the previous one. Rather, they form layers, overlapping and coexisting with each other. ${ }^{11}$ Maybe, it is more appropriate to speak not of phases, which evokes chronological succession, but of layers of salvation history. In the perspective of development, we live in an era when three layers are present: that of the order of creation, of Moses' Law and the layer of the New Testament. The last phase of salvation history is going to come: eschaton concluding the history of salvation during Christ's second coming. Sacraments will be redundant after the history of salvation has been completed.

All sacraments are sacraments of the Word. The Word of the Father through whom the universe was created (Hebr 1:2; John 1:3; Col 1:16) is mirrored in the created world and, therefore, the invisible creation is continually active and legible. This idea can be found in more passages from Paul's letters. According to Paul, pagans are able to know the real and true God, give thanks to him and worship him (Rom 1:19n; 1 Cor 1:21). This cannot be done without religious rituals. Thus Paul

10 See Thomas Aquinas, STh III. 61.2 ad 3.

11 See Benoît-Dominique de La Soujeole, Introduction au mystère de l'Eglise (Paris: Parole et Silence, 2006), 473. 
presupposes sacraments of the order of creation. Their form and religious content depend on the level of knowledge of God and are deeply influenced by cultural context. When elements of the created physical world are integrated into worship, the spiritual dimension of the creation comes to the surface. Man himself looks for adequate forms in which to worship God. Since God called upon Abraham and gave him the covenant, rituals, as the worshipful reply to God's self-revelation, form a specific category.

The sacraments of Moses' Law are also sacraments of the Word. The continuing revelation of God goes hand-in-hand with its tangible expression. A distinctive feature of sacraments of this period is God's initiative in the sense that God himself reveals the specific way in which he wants to be worshipped. Every event following the meeting of Moses with the God of Abraham, Isaac and Jacob evolves the revelation of God's name. Sacraments of this period exist as sacred rituals and are part of the liturgical service taking place in the temple, synagogues, and homes. Outer ritual performance, as well as the words of Moses and the other prophets, were directed towards the awaited Messiah. However, the temple in Jerusalem was demolished in the year $70 \mathrm{AD}$ and this kind of liturgical service ceased to exist, without being actually restored. ${ }^{12}$ Since then, even greater emphasis has been placed on the sacred texts. The Torah, the Prophets, and the Writings are the central sacraments of Moses' Law. This is proved by the fact that Israel has retained its religious identity even after the end of animal sacrifices. The synagogal liturgy focused on the listening and interpreting of the word of God has represented its essential part up to this day. Worship service taking place in the homes of God's people is related to the service in synagogues and concentrates on the sanctification of time through various feasts during the year.

The person of the Incarnated Word himself is the sacrament of the New Testament. He embodies a dimension of creation culminating in man. Human nature is received and connected with the divine and personalised in the Son of the Father in a unique way. Jesus Christ, being the highest sacrament, also contains the Scriptures of the fathers. After

12 There are still initiatives aiming to restore the temple in Jerusalem and its cult. See Olivier-Thomas Venard, Terre de Dieu et des hommes (Perpignan: Artège, 2012), 63-85. The cultic life of Israel is also preserved by the community of Samaritans on the Mount Gerizim. See AB Institute of Samaritan Studies, accessed December 20, 2019, https://www.israelite-samaritans.com. 
all, it was to him they were referring, or rather, it was he who spoke through them about himself. Jesus Christ is the perfect and complete revelation of God's name. Due to the incarnation of the Word, the fullness of divine life is present in the human nature of Jesus. Christ is the new Adam, not physical as the first but pneumatic. The perfection of this unique sacrament of the New Testament is realised in the connection of the Head with the body that is the whole Christ (totus Christus). Regarding the teaching of the Second Vatican Council, ${ }^{13}$ the Church as the mystical body of Christ is not a new, different sacrament but is in Christ like a sacrament, and thereby participates in the sacramentality of Christ. Therefore, the seven sacraments of the Church are the concrete realisations of this sacramental participation.

\section{The Church as the Mediator of all Sacraments}

The people of Israel sharing the sacraments of Moses' Law have not been able to support sacraments of the natural order as well. These sacraments have been understood as idolatry, and thus a threat to the belief in the one God of Israel. On the other hand, the idea of the universality of salvation connected with universal worship had been developing more and more throughout the history of God's nation.

The Church received Christ's fullness of revelation and, therefore, is able to see the economy of salvation as the whole; it is thus provided with certain freedom and confidence. Promises of the Messiah are no longer uncertain anticipations but the present reality. For in Christ, who is the head of the Church, all the fullness of deity was pleased to dwell bodily, as the apostle says (cf Col 1:19; 2:9). This pléroma of deity in bodily form is another feature of the universal sacramentality appropriate to Christ, in which the Church participates. The extensive sacramentality represents a frame unifying sacraments of all phases of the salvation economy. The Church, therefore, ought to operate with all types of sacraments while differentiating among them. Although we refer to the extensive sacramentality, this does not mean that we focus on the areas that we perceive outside the Church according to some set

13 For the application of the term sacrament on the Church in the documents of the Second Vatican Council see Benedikt Mohelník, 'Sebepojetí církve jako kněžského lidu a jeho vliv na svátostnou povahu církve,' in Prokop Brož et al., Církev a II. vatikánský koncil: Perspektivy současné eklesiologie (Červený Kostelec: Pavel Mervart, 2015), 163-168. 
criteria. On the contrary, even this type of sacramentality is directed inside the Church. Extensive is not the same as external. In this part of the paper, we will proceed in two steps. First, we will focus on the sacraments within the Church, and then we will focus on the sacraments outside the visible communion of the Church.

\subsection{The Sacraments inwards the Church}

An interior extensity (the paradox is only apparent, not real) is realised when Christians and Church communities explore the entire breadth, depth, and height of God's mysteries, and when sacraments penetrate all areas of the individual and communal life of Christians. According to St. Paul, the vocation of every Christian strengthening his or her inner being is to grow in knowing the love of Christ that surpasses human knowledge so that he or she may be filled with all the fullness of God (Eph 3:16-19). In this sense, the sacraments are extensive within the Church, while 'extensity' in this case means primarily growth in quality.

The 'traditional' pastoral approach to the sacraments has often been built on the assumption that children are continuously being formed by catechesis during the period of basic education, and thus naturally assimilate the Christian religious life. This assumption is not, in fact, valid these days or else applies to a minority of practising Christians. A significant part of Christians today has never gone through continuous catechesis nor has been supported by a Christian socio-religious environment; therefore, the meaning of mystagogy, not only as a part of the formation of neophytes but as the essential pastoral principle, is increasing in importance.

Many theological reflections are based on some observations as to how Catholics approach the sacraments nowadays, especially the Eucharist. Very few authors ask about the actual formation of believers and seem to automatically assume that all believers understand the mystery thoroughly enough. The approach of believers to the Eucharist is related to their education in faith and to their spiritual direction. If we understand the sacraments as the gifts of Christ himself to the Church, our pastoral praxis should depend on the specific meaning of the sacraments or, as St. Thomas would say, the truth of the sacrament is the one for the whole Church. The sacraments cannot be simply adapted to the changeable expectations of specific groups of believers. 
The unifying principle of the sevenfold organism of the New Testament sacraments is universal priesthood perfectly realised in the Eucharist where a spiritual sacrifice of believers is unified with the sacrifice of Jesus. ${ }^{14}$ I consider the spreading of the theology of the universal priesthood of all believers among laypeople in the Church as well as their shepherds to be the urgent challenge of sacramental theology nowadays. The theology and spirituality of the universal priesthood should always be the crucial theme of continual mystagogical formation in Christian communities.

\subsection{The Sacraments outwards the Visible Community of the Church}

An outer extensity covers all remaining groups of sacraments - sacraments of the Old Testament and sacraments of the natural order, eventually sacraments of promise, in case we would like to distinguish the period between the covenant given to Abraham and the calling of Moses. These sacraments can all be defined as the sacraments prior to the New Testament. ${ }^{15}$

The Second Vatican Council did not use the term sacrament related to religious expressions outside the visible community of the Church. Nevertheless, in my opinion, the teaching of the Council opens a door for further theological reflection upon the sacraments in the widest sense of the word. The constitution Gaudium et spes offers a Christological perspective of man, saying that: 'the truth is that only in the mystery of the incarnate Word does the mystery of man take on light' (GS 22). Thus the Church is able to see in the light of Christ's mystery Christic features and their potential in the sacraments prior to the New Testament. The Council says in the same paragraph that Christ reveals to man his personal vocation. This vocation is divine and one, the same for all people because Christ died for all, while 'the Holy Spirit,

14 See Benedikt Mohelník, 'Eucharistie - obět' Krista-Hlavy a jeho mystického Těla,' Acta Universitatis Carolinae Theologica 6, no. 1 (June 2016): 119-146, doi:10.14712/23363398.2016.7.

15 Primarily, I distinguish between sacraments prior to the New Testament and sacramentals which are fully appropriate only to Christians and with limits to non-baptised persons (above all to catechumens) - see $S C 60$. Therefore, I do not suppose that elaborating theology of sacraments would make a real contribution to this issue as it was proposed by Martin Stufflesser. See 'Observations sur la théologie des sacrements et de la sacramentalité, dans le contexte oecuménique,' La Maison-Dieu 292, no. 2 (June 2018): 23-24. 
in a manner known only to God, offers to every man the possibility of being associated with this paschal mystery' (GS 22). Another important practical indication can be found in the Decree on the Mission Activity of the Church: 'For the Church, although of itself including the totality or fullness of the means of salvation, does not and cannot always and instantly bring them all into action. Rather, she experiences beginnings and degrees in that action by which she strives to make God's plan a reality' ( $A G 6$ ). The means of salvation, which cannot always be brought into action, are here first of all the sacraments of the New Testament. Nevertheless, the Church is called upon to realise God's plan of salvation, therefore she must also use other means available.

So the Church ought also to operate with the sacraments of the natural order as well as with the sacraments of promise and sacraments of Moses' Law. Benedikt Kranemann raises a question as to how members of other religions or eventually people without religious beliefs can be integrated into ecumenical, that is, Christian worship. ${ }^{16}$ If we go beyond the ground plan of Christian liturgy in the strict sense, which is a natural expression of community among Jesus' disciples, we gain a new perspective. On the one hand, we do not enter into a conflict situation as we do when non-Christians are actively involved in Christian worship. On the other hand, this act of worship obtains a specific status and is not degraded as part of an undefined interspace - it is a sacrament. The Church definitely cannot substitute different religions performing their own specific religious rituals, yet it is completely legitimate if the Church involves representatives of different religions into common gatherings through their cultic acts arising from the Mosaic tradition or 'professing to hold the faith of Abraham, along with us adore the one and merciful God, who on the last day will judge mankind' ( $L G 16)$. In the same way, general spiritual symbols can be involved and used by any participant.

The Church should not accept the position of an institution specializing in rituals and providing, on a contract basis, a ceremonial aspect to public events. ${ }^{17}$ She can avoid this danger if she understands the task as part of her mission in the world realised through those sacraments prior to the New Testament. Acts of worship of the Church also

\footnotetext{
16 See Benedikt Kranemann, 'Společnost v poplachu katastrof: Perspektivy liturgické vědy při veřejných smutečních obřadech,' Salve 29, no. 1 (2019): 155-156.

17 Ibid., 154.
} 
have a diaconal dimension..$^{18}$ As a result, the Church would be able to accompany all people on their life's journey through a particular period of their personal salvation history. In this way, she does not abandon her essential vocation to proclaim the gospel to all nations, aiming to make possible for all to believe in Christ personally and become Christians. ${ }^{19}$ A perceptive spiritual accompaniment is more likely to avoid a threat of agitation having nothing in common with a real testimony of faith.

Christ himself gives an example of how all types of sacraments might be integrated. This is most evident in the case of the institution of the Eucharist which was established by Jesus gradually, so his disciples are able to perceive the meaning of this concentrated (as well as concentrating) sacrament. The institution is here understood in a broader sense of the word. The first stage of the institution is Jesus eating with his disciples, tax collectors, sinners, women, etc. A symbolic significance of food and dining as a sacrament of the natural order is here the centre. The second stage is the event of the last supper, clearly based on the sacrament of Moses' Law (paschal dinner, paschal temple liturgy etc.). Jesus wholly accepts the meaning of sacraments of the Moses' Law but at the same time, he releases them for a new, full, and perfect meaning. He anticipates the oncoming events of his death and resurrection. The third stage of the institution is the entrusting of the fully formed New Testament sacrament of the Eucharist to the early Church during the dining of Jesus with his disciples after the resurrection (Emmaus, at the shore of the lake, etc.). The fully established Eucharist celebrated by the Church does not miss any of the constitutive stages, but rather they are transformed into particular Christian liturgical forms. The symbolic meaning of basic food and common dining is always essential for the Eucharist; the elements of the sacraments of Moses' law are integrated (not only in the form of certain ritual continuity but also through the praxis of reading and interpreting the Scripture) together with totally new aspects, above all the personal presence of Christ in his paschal mystery.

The outer extensive sacramentality defines a form of the Church's action in the world. The universal sacramentality of Christ sets the

\footnotetext{
18 See Julia Knop, 'Diakonická církev v podmínkách diaspory,'S Salve 29, no. 1 (2019): 30-32.

19 See Kranemann, ‘Společnost v poplachu katastrof,' 154-155.
} 
frame of the action. Through her action, the Church, in a certain sense, giving the meaning to the salvation history, ${ }^{20}$ is called upon to reach to the farthest edge of the universal sacramentality that is all people without exception. Christ as the mediator and redeemer of all people is related to every individual human being. The extensive sacramentality has a centrical dynamic. It guides man to the innermost identification with Christ possible, realised in the Eucharist. Thus, the Church is established and sent to enable all people to participate in Christ's perfect spiritual sacrifice. This accompaniment is realised through all types of sacraments, from sacraments of the natural order, through sacraments of Moses' Law up to the sevenfold organism of the New Testament sacraments. ${ }^{21}$

Their common factor is represented by the essential aspect of the highest worship realised by Christ, the highest priest that gives himself to others. Every act of authentic love expressed for a neighbour might be joined to the love of Christ through the sacraments as the instruments or tools enabling us to do so. Particular types of sacraments differ in explicitness and intensity, yet all of them allow a real bond to Christ. The Church is equipped to discerning and she can even, in case of sacraments of the natural order, emphasize their aspects with a potential to heal, cultivate, etc. These elements, being a foundation of authentic significance, can be found among all types of sacraments prior to the New Testament. Regarding sacraments of the natural order, it is a symbolic expression of the longing for God and a transcendent meaning of life, often quite indefinite. Sacraments of promise articulate a belief in the one God who is merciful and just. Finally, the sacraments of Moses' Law declare the awaiting of the coming of the Messiah and the awareness of God's election.

God's blessing arising from the sacraments is for all people. Sacraments prior to the New Testament are also nowadays effective towards the faith which they express and encourage as well. Indeed, through the work of the Church, 'whatever good is in the minds and hearts of

20 See François Daguet, Théologie du dessein divin chez Thomas d'Aquin: Finis omnium Ecclesia (Paris: J.Vrin, 2003).

21 In a few sentences, I summarise here the teaching of the Second Vatican Council from the chapter on the people of God, LG 14-17. The council explicitly refers to the theology of St. Thomas Aquinas on the capital grace of Christ. Christ is the head of every man; therefore, all people are related to him although at various levels. See Thomas Aquinas, STh III. 8. 
men, whatever good lies latent in the religious practices and cultures of diverse peoples, is not only saved from destruction but is also cleansed, raised up and perfected unto the glory of God, the confusion of the devil and the happiness of man' (LG 17).

\section{Conclusion}

I realize that statements proposed in this short article require more detailed research and more precise argumentation. The magisterial texts, including documents of the Second Vatican Council I have been quoting from as well as Acta synodalia, should be studied further. However, I believe that the fundamental theological hypothesis which I offer is formulated clearly enough to become a subject of discussion. The sacramental service of the Church is neither limited nor exhausted in the celebration of the seven sacraments as canonically defined. The Church is sent to extend her visible boundaries towards the universal sacramentality of Christ, which can also be realised through sacraments prior to the New Testament. The conciliar vision of people who are looking for God but, for now, do not have the gift of faith and do not belong to the community of Jesus' disciples does not deny the existing dark side of reality: 'But often men, deceived by the Evil One, have become vain in their reasonings and have exchanged the truth of God for a lie, serving the creature rather than the Creator (cf. Rom 1:21.25). Or some there are who, living and dying in this world without God, are exposed to final despair' ( $L G 16$ ). Maybe, rather than using the scholastic terminology for the sacraments prior to the New Testament, we can call them the sacraments of humanity or the sacraments of hope.

Catholic Theological Faculty, Charles University Thákurova 3 16000 Praha 6 E-mail:mohelnik@ktf.cuni.cz. 